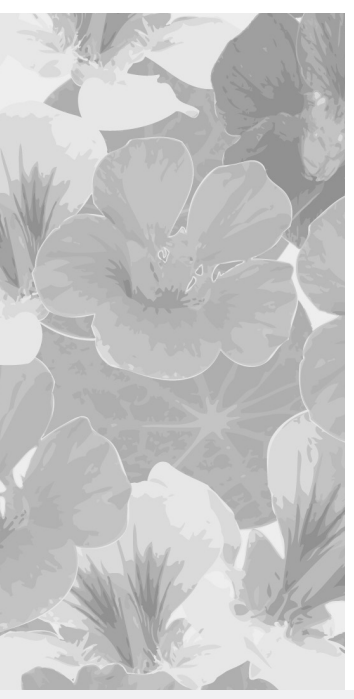

\title{
Częstość korzystania i poziom zadowolenia z mikrodermabrazji diamentowej wśród klientek salonu kosmetycznego
}

\author{
The frequency of using and level of satisfaction with diamond microdermabrasion \\ among clients of a beauty parlour
}

Magdalena Niewęgłowska-Wilk, Tomasz Wilk, Grażyna Kamińska-Winciorek, Radosław Śpiewak

Zakład Dermatologii Doświadczalnej i Kosmetologii, Wydział Farmaceutyczny

Uniwersytet Jagielloński Collegium Medicum, Kraków

Estetol Med Kosmetol 2011; 1(1): 17-19

http://dx.doi.org/10.14320/EMK.2011.003

\section{Streszczenie}

Cel: Celem pracy była ocena częstotliwości korzystania z zabiegu mikrodermabrazji diamentowej w obrębie twarzy i badanie poziomu zadowolenia z zabiegu w grupie klientek salonu kosmetycznego. Materiały i metody: W prywatnym salonie kosmetycznym w Krakowie przeprowadzono badania ankietowe klientek w wieku 20-30 lat podzielonych na dwie stuosobowe grupy. Pierwsza grupa (A) sktadała się ze 100 kolejnych spełniających kryterium wieku klientek salonu, które odpowiedziały na pytanie czy, i z jakiego powodu korzystają z mikrodermabrazji diamentowej. Druga grupa (B) obejmowała 100 klientek korzystających z mikrodermabrazji diamentowej, podzielonych w zależności od wskazania do zabiegu na 4 podgrupy po 25 osób, które odpowiadały na pytanie o częstość korzystania oraz poziom satysfakcji z zabiegu. Wyniki: Wśród 100 klientek salonu (grupa A) z zabiegu mikrodermabrazji diamentowej przynajmniej raz w życiu skorzystało $41 \%$. Wśród klientek korzystających z tego zabiegu (grupa B) $44 \%$ wykonywało ten zabieg tylko raz w roku. Zadowolenie z przeprowadzonej mikrodermabrazji już po pierwszym zabiegu zadeklarowało $39 \%$ ankietowanych. Najbardziej zadowolone (14 spośród 25 osób, 56\%) były osoby korzystające z zabiegu mikrodermabrazji diamentowej w celu redukcji przebarwień. Wnioski: Kobiety w wieku 20-30 lat korzystają najczęściej z jednego zabiegu mikrodermabrazji diamentowej w roku, a satysfakcjęjuż po pierwszym zabiegu najczęściej zgłaszają osoby korzystające z tej metody w celu redukcji przebarwień skóry twarzy.

Stowa kluczowe: mikrodermabrazja diamentowa, ztuszczanie warstwy rogowej, przebarwienia, ostudy

\begin{abstract}
Aim: To study the frequency of using diamond microdermabrasion on the face and the level of satisfaction among female clients of a beauty parlour. Materials and methods: In a private beauty parlour in Krakow, Poland, a questionnaire survey was conducted among female clients 20-30 years old, divided into two groups each of 100 persons. The first group (A) included one hundred consecutive clients, who answered to the questions whether, and how often they undergo diamond microdermabrasion. The second group (B) included another 100 women who have hat at least one diamond microdermabrasion treatment, divided into 4 groups each of 25 depending on the indication for the treatment, who answered questions about the frequency of use, and the level of satisfaction of the treatment. Results: Out of 100 consecutive clients (group A), 41\% have had the diamond microdermabrasion treatment at least once in their life. Among those who had undergone the treatment (group B), $44 \%$ did it once in a year only. $39 \%$ of the surveyed women declared their satisfaction with diamond microdermabrasion already after the first treatment. Most satisfied (14 out of 25 persons, $56 \%$ ) were those undergoing microdermabrasion for the reduction of skin discolourations. Conclusions: Most women aged from 20-30 undergo one diamond microdermabrasion treatment per year. Most satisfied are those who receive the treatment for skin discolourations.
\end{abstract}

Keywords: diamond microdermabrasion, stratum corneum exfoliation, hyperpigmentation, melasma

Copyright @ 2011 the Authors (text) and Radosław Śpiewak (layout \& journal compilation). All rights reserved.

Mikrodermabrazja diamentowa jest popularną metodą złuszczania naskórka wykonywaną w gabinetach kosmetycznych i lekarskich. Polega na mechanicznym ścieraniu warstwy rogowej naskórka za pomocą różnej wielkości głowic pokrytych drobnymi ziarnami diamentu napędzanymi podciśnieniem z pomocą pompy zasysającej. Metoda ta jest wykorzystywana $\mathrm{w}$ redukcji przebarwień, blizn, zmarszczek wokół oczu i ust oraz rozstępów, znalazła także zastosowanie w poprawie wyglądu skóry w przebiegu trądziku pospolitego, redukcji blizn potrądzikowych, zmniejszenia łojotoku, a także w usuwaniu szorstkiego, zrogowaciałego naskórka.

\section{Cel pracy}

Celem pracy była ocena częstości korzystania z mikrodermabrazji diamentowej w obrębie twarzy, a także ocena satysfakcji $\mathrm{z}$ tego zabiegu przeprowadzonego $\mathrm{w}$ celu redukcji przebarwień, łojotoku, szorstkiego i zrogowaciałego naskórka oraz blizn potrądzikowych w grupie młodych klientek wybranego gabinetu kosmetycznego. 


\section{Materiat i metody}

Badanie ankietowe przeprowadzono w dwóch stuosobowych grupach młodych kobiet w wieku od 20 do 30 lat, które skorzystały $\mathrm{z}$ usług salonu kosmetycznego w Krakowie. Grupa A składała się ze 100 kolejnych kobiet zgłaszających się do prywatnego salonu kosmetycznego. Grupa B obejmowała 100 kolejnych kobiet korzystających w tym salonie z zabiegów mikrodermabrazji diamentowej, podzielonych na cztery 25-osobowe podgrupy według wskazań do zabiegu (redukcja przebarwień potrądzikowych na twarzy, zmniejszenie łojotoku, redukcja blizn lub redukcja szorstkiego i zrogowaciałego naskórka). Zabiegi były wykonane przez tego samego kosmetologa. Badanie ankietowe składało się z 2 głównych części - w pierwszej pytano o częstość korzystania z zabiegów mikrodermabrazji, ich rodzaj i liczbę (ryc. 1), w drugiej części oceniano poziom satysfakcji badanych z zabiegu (ryc. 2).

Rycina 1. Ankieta dotycząca korzystania z zabiegu mikrodermabrazji diamentowej (grupa A)

ANKIETA (cz. I)
1. Czy korzysta Pani z zabiegu mikrodermabrazji diamentowej?
$\square$ Tak
$\square$ Nie
2. Z ilu zabiegów mikrodermabrazji diamentowej korzysta Pani w ciągu jednego roku?
$\square$ Dwóch zabiegów w miesiącu
$\square$ Jednego zabiegu w miesiącu
$\square$ Jednego co 2-3 miesiące
$\square$ Jeden zabieg co 6 miesięcy
$\square$ Jeden zabieg raz w roku

Rycina 2. Ankieta dotycząca poziomu zadowolenia w grupie klientek korzystających z zabiegu mikrodermabrazji diamentowej (grupa B)

ANKIETA (cz. II)
1. Jaki jest powód, dla którego korzysta Pani z zabiegu mikrodermabrazji diamentowej?
$\square$ Redukcja przebarwień na twarzy
$\square$ Zmniejszenie łojotoku
$\square$ Redukcja blizn potrądzikowych
$\square$ Redukcja szorstkiego, zrogowaciałego naskórka
2. Czy zaobserwowała Pani poprawę stanu skóry po pierwszym zabiegu mikrodermabrazji
diamentowej?
$\square$ Tak
$\square$ Nie

\section{Wyniki}

Wyniki w pierwszej fazie badania przeprowadzonej w grupie A wykazały, 41\% klientek salonu kosmetycznego przynajmniej raz w życiu skorzystało z zabiegu mikrodermabrazji diamentowej (ryc. 3). Częstotliwość korzystania z zabiegów w tej grupie przedstawia rycina 4 . W drugiej części badania (grupa B) satysfakcję $\mathrm{z}$ efektów mikrodermabrazji diamentowej najczęściej zgłaszały klientki korzystające z zabiegu w celu redukcji przebarwień oraz zmniejszenia łojotoku (tab. 1).

Rycina 3. Korzystanie z zabiegów mikrodermabrazji diamentowej wśród kolejnych klientek salonu kosmetycznego (grupa A)

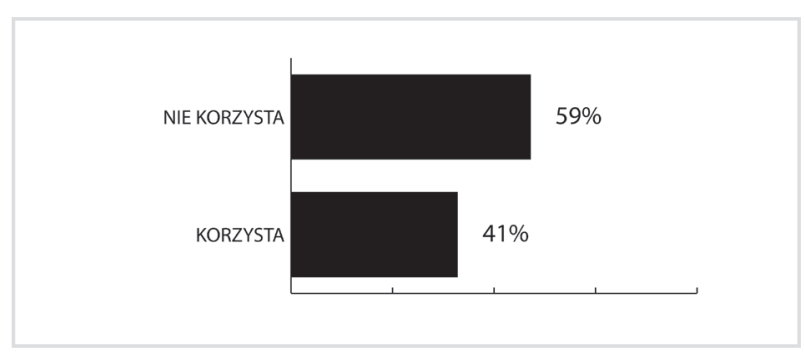

Rycina 4. Częstotliwość korzystania z zabiegów mikrodermabrazji diamentowej (grupa A)

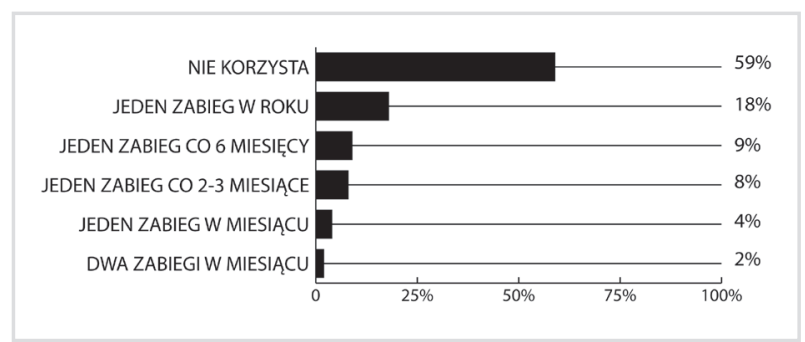

Tabela 1. Ilość klientek deklarujących satysfakcję wśród osób korzystających z mikrodermabrazji diamentowej. Wyniki w grupie B podzielonej na cztery podgrupy po 25 osób w zależności od wskazań do zabiegu

\begin{tabular}{l|l}
$\begin{array}{l}\text { Powód wykonywania } \\
\text { mikrodermabrazji diamenowej } \\
\text { w obrębie twarzy }\end{array}$ & $\begin{array}{l}\text { Liczba (\%) osób } \\
\text { zadowolonych } \\
\text { z efektu zabiegu }\end{array}$ \\
\hline Redukcja przebarwień $[\mathrm{N}=25]$ & $14(56 \%)$ \\
\hline Zmniejszenie łojotoku [N=25] & $13(52 \%)$ \\
\hline $\begin{array}{l}\text { Redukcja szorstkiego, zrogowaciałego } \\
\text { naskórka } \\
{[\mathrm{N}=25]}\end{array}$ & $8(32 \%)$ \\
\hline Redukcja blizn potrądzikowych $[\mathrm{N}=25]$ & $4(16 \%)$ \\
\hline
\end{tabular}

\section{Dyskusja}

Zabiegi dermabrazji, w tym mikrodermabrazji wykonuje się od ponad 20 lat, głównie w celu poprawy tekstury skóry, redukcji blizn oraz resurfacingu. W porównaniu z dermabrazją, mikrodermabrazja cechuje się słabszym efektem, ale zarazem 
krótszym okresem gojenia i mniejszą liczbą powikłań [1]. Mikrodermabrazja należy do technik ablacyjnych, które wpływają na reepitelizację, czyli odtwarzanie naskórka [2]. Jest to zabieg, na który decyduje się coraz więcej klientów. Według badań z 2008 roku, liczba zabiegów medycyny estetycznej, w tym mikrodermabrazji, wzrosła w ciągu ostatnich 10 lat bez mała pięciokrotnie [3]. Aktualnie stosuje się głównie dwa typy mikrodermabrazji: mikrodermabrazję diamentową z zastosowaniem różnej grubości ziaren diamentowych, które zasysane podciśnieniem w głowicach o różnych rozmiarach delikatnie ścierają naskórek, oraz mikrodermabrazję korundową, w której wykorzystuje się ścierne właściwości kryształów tlenku aluminium. Mikrodermabrazja diamentowa ma wpływ na przebudowę kolagenu, comożewskazywaćnajej pozytywnedziałanie w przypadku poprawy skóry starzejącej się, przy czym efekt ten wydaje się zależny od stosowanych nasadek (a zatem grubości ziarnistości). Zastosowanie nasadek diamentowych o grubej ziarnistości doprowadza do gwałtownej indukcji cytokeratyny 16 oraz aktywacji markerów procesu zapalnego, m.in. cytokin prozapalnych, peptydów przeciwbakteryjnych oraz wywołuje nacieki neutrofilowe w skórze właściwej, przypominając pod tym względem proces gojenia rany i przebudowy kolagenu [4]. Mikrodermabrazja jest często stosowana $\mathrm{w}$ celu poprawy wyglądu skóry w przebiegu trądziku zwykłego i redukcji drobnych blizn potrądzikowych [5,6], choć część autorów ocenia efektywność tej metody w redukcji blizn potrądzikowych jako niewielką [4]. Mikrodermabrazja poprawia wygląd skóry głównie poprzez usuwanie zrogowaciałego naskórka, redukcję łagodnych przebarwień, wygładzenie powierzchni skóry, niwelowanie delikatnych zmarszczek oraz ograniczenie łojotoku [3]. Badania wskazują również na skuteczność mikrodermabrazji w redukcji uszkodzeń posłonecznych i drobnych zmarszczek [6]. Zazwyczaj zaleca się serię 6 zabiegów mikrodermabrazji powtarzanych co 2-4 tygodnie [3]. Po sześciu sesjach mikrodermabrazji obserwowano obniżenie produkcji łoju [7]. $\mathrm{W}$ połączeniu $\mathrm{z}$ preparatami o działaniu wybielającym (np. wyciąg z lukrecji, preparaty arbutyny, soi, N-acetyloglukozaminy i niacyny) mikrodermabrazja wykazuje korzystne działanie redukcji przebarwień [8]. Rozjaśnienie kolorytu skóry po mikrodermabrazji potwierdzono również w obiektywnych badaniach z zastosowaniem kolorymetrii [9].

\section{Wnioski}

Większość kobiet wykonuje zabieg mikrodermabrazji diamentowej tylko jeden raz w ciągu roku. Najbardziej zadowolone z efektów już po jednym zabiegu są kobiety poddające się mikrodermabrazji diamentowej w celu redukcji przebarwień skóry.

\section{Piśmiennictwo}

1. Gold MH: Dermabrasion in dermatology. Am J Clin Dermatol 2003; 4(7): 467-71.

2. Karimipour DJ, Rittie L, Hammerberg C, Min VK, Voorhees JJ, Orringer JS, Sachs DL, Hamilton T, Fisher GJ: Molecular analysis of aggressive microdermabrasion in photoaged skin. Arch Dermatol 2009; 145(10): 1114-22.

3. Small R: Aesthetic procedures in office practice. Am Fam Physician 2009; 80(11): 1231-7.

4. Karimipour DJ, Karimipour G, Orringer JS: Microdermabrasion: an evidence-based review. Plast Reconstr Surg 2010; 125(1): 372-7.

5. Fabbrocini G, Annunziata MC, D'Arco V, De Vita V, Lodi G, Mauriello MC, Pastore F, Monfrecola G: Acne scars: pathogenesis, classification and treatment. Dermatol Res Pract 2010; 2010: 893080.

6. Neil S, Sadick MD, Neil A, Finn BA: Nowe zastosowania w technologii mikrodermabrazji, Dermatol Estet 2003; 1(24): 12-15.

7. Davari P, Gorouhi F, Jafarian S, Dowlati Y, Firooz A: A randomized investigator-blind trial of different passes of microdermabrasion therapy and their effects on skin biophysical characteristics. Int J Dermatol 2008; 47(5): 508-13.

8. Grimes PE: Management of hyperpigmentation in darker racial ethnic groups. Semin Cutan Med Surg 2009; 28(2): 77-85.

9. Spencer JM, Kurtz ES: Approaches to document the efficacy and safety of microdermabrasion procedure. Dermatol Surg 2006; 32(11): 1353-7.

\section{Finansowanie i konflikt interesów}

Przedstawione badania i przygotowanie niniejszej publikacji zostało w całości sfinansowane $\mathrm{z}$ własnych środków autorów. Wszyscy autorzy deklarują niewystępowanie konfliktu interesów w odniesieniu do treści zawartych w niniejszej pracy.

\section{Adres do korespondencji:}

mgr Magdalena Niewęgłowska-Wilk

Zakład Dermatologii Doświadczalnej i Kosmetologii UJ CM, ul. Medyczna 9, 30-688 Kraków

tel.: 1262058 30, fax: 126205645

e-mail: magdalena.nieweglowska-wilk@uj.edu.pl

Data złożenia: 21.07 .2011

Data akceptacji: 30.07 .2011

Data aktualizacji: 30.11.2011 